\title{
REGIONAL APPLICATION OF THE GROSS NATIONAL HAPPINESS INDEX IN THE CONTEXT OF THE QUALITY OF LIFE IN SLOVAKIA
}

\author{
Radoslav Klamár, Anna Gaval'ová* \\ * University of Prešov, Faculty of Humanities and Natural Sciences, Department of Geography and Applied \\ Geo-informatics, ul. 17. novembra 1, 08116 Prešov, Slovakia, \\ radoslav.klamar@unipo.sk, zidovaanna@gmail.com
}

\begin{abstract}
Regional application of the Gross National Happiness Index in the context of the quality of life in Slovakia

The paper aims to apply the regional application of the Gross National Happiness Index (GNH Index) in the regions of Slovakia. The GNH Index, using the set of nine domains and several indicators within them, primarily aims to assess the comfort of inhabitants and their subjective happiness in the broader context of the quality of life concept. It points at the fact that the overall prosperity and development in the regions cannot be looked at only from the perspective of economic growth, using the gross domestic product as the most important economic indicator. Moreover, it should be approached in a more complex way. The original methodology of the GNH Index used in Bhutan was adapted to the conditions of Slovakia and its regions. The resulting values of the observed index were confronted, in the interregional comparison, with the values of the regional GDP using the Gini coefficient and coefficient of variation as the basic statistic measures of the assessment.
\end{abstract}

Key words: Gross National Happiness Index, domains, quality of life, gross domestic product, Gini coefficient, coefficient of variation, self-governing regions, Slovakia

\section{INTRODUCTION}

Since the middle of the 20th century, western society has undergone important political, economic and social changes. As a result, the growth of prosperity and wealth occured, but, on the other hand, the measure of the satisfaction of its inhabitants with their lives has not increased at the same time. The relationship between the growing physical wealth and simultaneously not growing, and in some cases what feels like declining personal happiness, is named "Easterlin paradox" or "Easterlin paradox of happiness" by economists (Mlčoch 2005).

Most people are convinced that happiness and satisfaction with life is the choice of an individual. Happiness seems to be deeply subjective and vague to serve as a cornerstone for the objectives of the nation and its policy content. It seems that this traditional view has been changing. It was proven in a survey in 2006 that $81 \%$ of the UK population agreed that the Government's primary objective should have been the creation of happiness not wealth (Easton 2006 in White 2007). David Cameron put happiness firmly on the political agenda by arguing that "It's time we admitted that there's more to life than money, and it's time we focused not just on GDP, but on GWB - general well-being" (White 2007, p. 1).

At present, in spite of this, economies of states make an enormous effort to obtain the highest economic growth monitored by the GDP in the country. According 
to several authors, the policy of state, should be more aimed at happiness and the satisfaction of the inhabitants with their lives rather than only the economic growth of the country (Sachs 2012 in Helliwell et al. 2012). Similarly, Ira and Murgaš (2008) present the idea that the focus of society on wealth, profitability, and a consumer way of life is perceived as unilateral by a lot of people. Alongside the interest of the non-physical/material value investigation, quality of life, as the most complex concept, has come into prominence. The quality of life, according to Bianchi (2005), has been attempted to be defined in a complex manner by several institutions with various political and value backgrounds and approaches.

One of them is the Gross National Happiness Index, which is focus of attention in this paper. The main objective of this work is its regional application within the scope of Slovak regions at NUTS 3 (regions) in the context of the quality of life.

\section{GROSS NATIONAL HAPPINESS INDEX IN THE CONTEXT OF THE QUALITY OF LIFE}

As mentioned above, in the assessment of the individual self-governing regions (hereinafter regions) of Slovakia only economic categories cannot be taken into account, but it is necessary to arise from a more complex and broader understood framework providing the concept of the quality of life and especially the existence of its two fundamental dimensions. It is a subjective dimension (individual, personal and private) and objective dimension (public, social and environmental). The quality of life can be understood as a result of the interaction between these two dimensions or the interaction between outer impacts and the inner "environment" of an individual (for example, in the works of Dissart and Deller 2000, Massam 2002, Pacione 2003, Andráško 2005 and 2016, Ira 2005 and 2010, Ira and Andráško 2007, Ira and Murgaš 2008, Murgaš 2008, Godor and Horňák 2010, Kačmárová et al. 2013 and Rišová 2016). Basically, it can be said, that the objective dimension of the quality of life represents (external) conditions and impacts of the surrounding environment and life circumstances on the life of an individual. In most cases they can be divided into social, economic and environmental. On the other hand, the subjective dimension represents the complex of subjective inputs of each individual such as opinions, attitudes, individual system of values, the ability of adaptation, the way of perception of the environment and others (Ira and Andráško 2007).

At the beginning, attention was especially paid to economic and social indicators of the quality of life: income and financial security, political freedom and independence, social justice, legal stability and healthcare. Later, attention was paid to subjective indicators of the quality of life, subjective comfort and satisfaction with life (Diener and Suh 1997). In this sense, the quality of life is understood by Veenhoven (1997), who thinks this term currently denotes two meanings: 1) the presence of conditions deemed necessary for a good life and 2) the practice of good living as such. As he continues, there are two other terms used as synonyms to the term quality of life: satisfaction with life and subjective comfort. Furthermore, the question is becoming complicated by the fact that it completes another term - happiness, whereby, in his view, satisfaction with life means the same and it is used as the substitution for the term happiness (Džuka 2004). 
Heřmanová (2012) also works with the feeling of happiness and degree of life satisfaction, and she focuses on subjective aspects of the quality of life. Bačová (2004) states that there are a lot of psychological measures investigating "subjecttive" indicators of life comfort, living happiness and enjoyment in life. These indicators measure satisfaction with life (Eurobarometer), happiness and the expectancy of a happy life (Happy Life Expectancy).

According to Rybářová et al. (2006), in the survey of the quality of life, the transfer from objective to subjective indicators, from group to individual ones and the transfer from investigating negative phenomena to positive ones and investigating variables such as happiness and enjoyment is performed.

The complexity of the question of the quality of life is also seen within its measurement. Its duality is demonstrated here in the form of objective and subjective dimensions.

In an objective investigation there is a need for selecting indicators. The advantages of objective indicators of the quality of life are as follows: easy definability, quantifiability and comparability. Their weaknesses are connected with data measuring, and in case of weak knowledge of the investigated territory, with the interpretation of results. The objective indicators do not reflect the perception of inhabitants (Diener and Suh 1997). The subjective approach to measurement of the quality of life is closer to the inhabitants of the given territory. The evaluation of results is less demanding as it is possible to use one variable in all measurements and it is satisfactory (Rišová 2016). Similarly, Babinčák (2013) states that the most used concepts for the subjective assessment of the quality of life are satisfaction, subjective comfort and happiness.

At present, the most often used approach in the quality of life measurement is making composite indexes. Andráško (2016) says that the method of their construction consists in that the selected partial dimensions of the quality of life are evaluated or quantified at first, and then the obtained figures are "added up" in a certain way with the aim to obtain data, which should express the level of the quality of life of an individual or a group of people in a complex way.

Indicators/indexes are used for the expression of quantity in the selected spheres of the quality of life within ordinary applied methods (Andráško 2016). Murgaš (2008) indicates them as indicators, components, criteria, agents, domains and subdomains.

In most of the work dealing with the assessment of the quality of life, it is possible to see a consistent effort for aggregation of larger number of indicators into several spheres or domains (Godor and Horňák 2010). In the assessment of the quality of life in the suburban space of Bratislava, Spišiak and Danihelová (1998) used 6 fields: environment, housing, civic amenities, location, demography and conditions of housing. Ira et al. (2005), in the research of districts in Slovakia, also grouped the indicators into 6 dimensions: demographic, educational and informational, security, material/financial comfort and social security, house equipment and environmental. Ira and Šuška (2006) divided the indicators into 5 fields: demographic, economic, location and availibility, housing and household equipment and environmental. Murgaš (2009) used domains such as prosperity, deprivation and human capital. According to Godor and Horňák (2010) almost all Slovak authors aggregate indicators into $5-7$ domains. 
The survey of indicators and domains selection in the foreign bibliography is given in the works of Džuka (2004), Ira and Andráško (2007), Ira and Murgaš (2008), Murgaš (2009), Andráško (2016) and Rišová (2016). Dissart and Deller (2000) think that the list of the quality of life components is in fact unlimited. In spite of this fact, they emphasize some key spheres of the life of an individual: personality, social support, satisfaction with some spheres of life, own abilities, environmental and economic factors, health, and stressful events and impacts.

In this context, Veenhoven (1996, p. 1) says, that "one of the aims of social indicator research is to develop a comprehensive measure of quality-of-life in nations that is analogous to GNP in economic indicator research. For that purpose, several multidimensional indexes have been proposed". These indexes can be completed by e.g. Human Development Index, Legatum Prosperity Index, Better Life Index and Gross National Happiness Index (e.g. in the works of Bianchi 2005, Kollár and Rusko 2012, Rubisová 2012, Naščáková et al. 2015, Murgaš 2015 and other).

Attention is also paid to the Gross National Happiness Index (hereinafter referred to as the GNH Index). This concept was introduced for the first time in 1972 by the Bhutan King J. S. Wangchuck as "development with values". Ura et al. (2012) indicate that the quality of the country is measured more holistically by the GNH Index rather than by GDP, and they are convinced, that the real development of the country takes place where the material and spiritual development exist sideby-side and where they strengthen each other.

\section{METHODS AND USED DATA}

The aim of this work is to regionally apply the Gross National Happiness Index within Slovak self-governing regions at a regional level. The original methodology of the Index GNH in Bhutan (The GNH Centre Bhutan), in the town of Thimphu served as the starting point (Ura et al. 2012). Based on the fact that Bhutan is culturally, politically and economically different from Slovakia, it was necessary to modify the index for the conditions of the Slovak Republic (SR).

The application of the GNH Index to the regional conditions of the SR consisted of several steps. At first, the main domains were selected. In terms of the biggest complexity, all 9 main domains from the original methodology of the GNH Index were applied (psychological, health, education, cultural diversity, good governance, vitality of society, environment, living standards and time use). Next, particular indicators for the main domains were selected. As some of the indicators were not relevant for the Slovak environment, out of 33 indicators applied in the original GNH Index, only 20 were defined for the analysis within Slovakia (e.g. literacy indicator - it is taken for granted in Slovak environment; Zorich Chusum skills indicator and Driglam Namzha - the indicator of the code of etiquette and conduct in Bhutan, etc.). Another step was to choose individual variables, which further served as specific questions in the questionnaire (serving as the input source). There were 100 variables in the original methodology of the GNH Index. For Slovakia, only 52 variables were applied. Their selection was restricted, similarly as in the case of indicators. In the elimination of individual variables, we focused on the importance of indicators. The questions which were not given great importance were eliminated. The selection of variables was sensitive and all the modifications to the methodology were consulted with the GNH Centre Bhutan. 
Consultations with the GNH Centre Bhutan proved to be effective in fixing the sufficiency threshold, which any respondent had to achieve in all variables in order to be considered happy. With regard to the differences between Slovakia and Bhutan, the sufficiency threshold had to be set differently. Setting indicators weights was another step. In their setting, the principle was: the bigger informative value of the indicator, the bigger the weight of the specific indicator. As only 20 indicators were used, it was necessary to adjust the original weights. An individual weights setting was also consulted with the GNH Centre Bhutan. Recalculated weights for individual indicators together with a sufficiency threshold for individual variables are indicated in Tab. 1.

After defining all the domains, indicators, variables, a sufficiency threshold and weights, it was necessary to define the happiness threshold for individual indicators at first. If the respondent had reached the sufficiency threshold of $66 \%$ in all assessed indicators of one particular domain, it would have been considered to be successful.

The next step was to identify two groups of people: happy and not-yet-happy. The respondent had to reach the happiness threshold in 6 out of 9 domains in order to be evaluated as happy (Ura et al. 2012). Another step was to define the percentage of domains among not-yet-happy people, in which the respondents reached or did not reach the happiness threshold. The last step was the actual calculation of the GNH Index by means of:

$$
G N H=1-\left(H_{n} \cdot A_{n}\right),
$$

where $H_{n}$ represents the percentage of not-yet-happy people and $A_{n}$ represents the percentage of domains in which not-yet-happy people did not reach the happiness threshold. The result is the number from 0 to 1 , whereby the closer the Figure is to 1, the higher the level of happiness is (Ura et al. 2012).

Thus, the prepared GNH Index was transformed into a questionnaire. Its distribution was (with respect to the scope of 52 questions) realized via Survio service (a tool for conducting marketing research and other online questionnaires). The distribution of the questionnaires was conducted in electronic form, using also mail communication and social networks. Data collection took place from 12/2015 to $3 / 2016$ and in total, 817 questionnaires were assessed.

In the end, the obtained figures of the GNH Index in individual regions were compared to the GDP per capita (2015), the most used economic index, whereby the Gini coefficient and coefficient of variation were used as statistical measures.

\section{ACHIEVED OUTCOMES}

For the purposes of the GNH Index assessment in Slovak regions, 817 questionnaires were used ( $56 \%$ of women and $44 \%$ of men). In terms of age structure, $36 \%$ of the respondents were in the 20 - to 29 -year-old age-group. The following age group consisted of the respondents aged from 30 to $39(26 \%), 40-49(19 \%), 50-$ $59(13 \%)$. The lowest number of respondents were in the age-group of over 60 $(6 \%)$. In terms of educational attainment, respondents with secondary education represent the highest portion $(58 \%)$, followed by respondents with higher education $(33 \%)$ and $9 \%$ of respondents had primary education. The penultimate area of research was the area of income, given in the following intervals: $0-€ 400(39 \%)$, $401-€ 900(41 \%)$, and $€ 900$ and more (20\%). The value of $€ 400$ represented the 
minimum wage in SR (in 2016 it was $€ 405$ ) and $€ 900$ represented the average wage in Slovakia (in 2016 it was $€ 912$ ). The structure, according to individual regions, was the last researched category. The highest number of respondents came from the Prešov region (19\%) and the Košice region (16\%), followed by the Bratislava region (13\%), the Žilina region (12\%) an the Nitra and Banská Bystrica regions $(11 \%)$. The lowest percentage of respondents was from the Trnava and the Trenčín regions $(9 \%)$. This structure approximately corresponds to the size structure of the regions according to the number of their inhabitants.

Tab. 1. Over-transformed GNH Index for Slovak conditions (domains, indicators and sufficiency threshold)

\begin{tabular}{|c|c|c|c|c|}
\hline Domain & Indicator (weight) & Variable/question & $\begin{array}{c}\text { Scope } \\
\text { of responses } \\
\text { for individual } \\
\text { variables }\end{array}$ & $\begin{array}{l}\text { Sufficiency } \\
\text { threshold }\end{array}$ \\
\hline \multirow{16}{*}{ Psychological } & Satisfaction with & How satisfied are you with your health? & \multirow{5}{*}{$\underset{(\min )}{25(\max )}-5$} & \multirow{5}{*}{$20-25$} \\
\hline & your life & How satisfied are you with your level of living? & & \\
\hline & & How satisfied are you with your employment? & & \\
\hline & & $\begin{array}{l}\text { How satisfied are you with the relationships } \\
\text { in your family? }\end{array}$ & & \\
\hline & & $\begin{array}{l}\text { How satisfied are you with the balance in your } \\
\text { work life? }\end{array}$ & & \\
\hline & $\begin{array}{l}\text { Spiritual area } \\
33 \%\end{array}$ & $\begin{array}{l}\text { To what extent do you consider yourself } \\
\text { a religious person? }\end{array}$ & $4 \underset{(\min )}{\max )}-1$ & 2 \\
\hline & Positive emotions & How often have you felt peaceful lately? & \multirow{5}{*}{$\underset{(\min )}{20(\max )}-5$} & \multirow{5}{*}{$20-15$} \\
\hline & $17 \%$ & How often have you felt compassion lately? & & \\
\hline & & How often have you felt forgiveness lately? & & \\
\hline & & How often have you felt satisfaction lately? & & \\
\hline & & How often have you felt generosity lately? & & \\
\hline & \multirow{5}{*}{$\begin{array}{c}\text { Negative emotions } \\
17 \%\end{array}$} & How often have you felt selfishness lately? & & \\
\hline & & How often have you felt jealous lately? & & \\
\hline & & How often have you felt fear lately? & $20(\max )-5$ & $20-15$ \\
\hline & & How often have you felt worries lately? & & \\
\hline & & How often have you felt anger lately? & & \\
\hline \multirow{2}{*}{ Health } & $\begin{array}{l}\text { Health } \\
25 \%\end{array}$ & How do you rate your health? & $5(\max )-1$ & $5-4$ \\
\hline & $\begin{array}{l}\text { Health restrictions } \\
75 \%\end{array}$ & Do you have long-term health problems? & $2 \underset{(\min )}{2(\max )}-1$ & 2 \\
\hline \multirow{9}{*}{ Education } & $\begin{array}{l}\text { Education } \\
\quad 43 \%\end{array}$ & $\begin{array}{l}\text { What is your highest level of education } \\
\text { achieved? }\end{array}$ & $3(\max )-1$ & 2 \\
\hline & $\begin{array}{l}\text { Knowledge } \\
28.5 \%\end{array}$ & $\begin{array}{l}\text { How would you rate your knowledge of tradi- } \\
\text { tions in the Slovak Republic? }\end{array}$ & \multirow{3}{*}{$15(\max )-3$} & \multirow{3}{*}{$15-10$} \\
\hline & & $\begin{array}{l}\text { How would you rate your knowledge of the } \\
\text { Constitution of the Slovak Republic? }\end{array}$ & & \\
\hline & & $\begin{array}{l}\text { How would you rate your knowledge of Slovak } \\
\text { national holidays? }\end{array}$ & & \\
\hline & \multirow{5}{*}{$\begin{array}{l}\text { Values } \\
28.5 \%\end{array}$} & In your opinion, is it possible to forgive murder? & \multirow{5}{*}{$15(\max )-3$} & \multirow{5}{*}{$15-14$} \\
\hline & & In your opinion, is it possible to forgive theft? & & \\
\hline & & In your opinion, is it possible to forgive a lie? & & \\
\hline & & $\begin{array}{l}\text { In your opinion, is it possible to forgive the } \\
\text { formation of unrest in interpersonal relation- } \\
\text { ships? }\end{array}$ & & \\
\hline & & $\begin{array}{l}\text { In your opinion, is it possible to forgive sexual } \\
\text { misconduct? }\end{array}$ & & \\
\hline
\end{tabular}


GEOGRAFICKÝ ČASOPIS / GEOGRAPHICAL JOURNAL 70 (2018) 4, 315-333

\begin{tabular}{|c|c|c|c|c|}
\hline Domain & $\begin{array}{l}\text { Indicator } \\
\text { (weight) }\end{array}$ & Variable/question & $\begin{array}{l}\text { Scope of responses } \\
\text { for individual } \\
\text { variables }\end{array}$ & $\begin{array}{l}\text { Sufficiency } \\
\text { threshold }\end{array}$ \\
\hline $\begin{array}{l}\text { Cultural } \\
\text { diversity }\end{array}$ & $\begin{array}{c}\text { Participation } \\
\text { in cultural } \\
\text { events } \\
100 \%\end{array}$ & $\begin{array}{l}\text { How many days a year do you participate in social and } \\
\text { cultural activities (festivals, etc.)? }\end{array}$ & $5(\max )-1(\min )$ & $4-3$ \\
\hline \multirow{9}{*}{$\begin{array}{l}\text { Good } \\
\text { governance }\end{array}$} & \multirow{7}{*}{$\begin{array}{c}\text { Government } \\
\text { performance } \\
16.5 \%\end{array}$} & $\begin{array}{l}\text { Evaluate the performance of government in creating } \\
\text { job opportunities. }\end{array}$ & \multirow{7}{*}{$\begin{array}{l}35(\max )-7 \\
(\min )\end{array}$} & \multirow{7}{*}{$28-25$} \\
\hline & & $\begin{array}{l}\text { Evaluate the performance of government in mitigating } \\
\text { the difference between the poor and the rich. }\end{array}$ & & \\
\hline & & $\begin{array}{l}\text { Evaluate the performance of government in the fight } \\
\text { against corruption. }\end{array}$ & & \\
\hline & & $\begin{array}{l}\text { Evaluate the performance of government in preserving } \\
\text { culture and traditions. }\end{array}$ & & \\
\hline & & $\begin{array}{l}\text { Evaluate the performance of government in environ- } \\
\text { mental protection. }\end{array}$ & & \\
\hline & & $\begin{array}{l}\text { Evaluate the performance of government in delivering } \\
\text { educational needs. }\end{array}$ & & \\
\hline & & $\begin{array}{l}\text { Evaluate the performance of government in improving } \\
\text { healthcare services. }\end{array}$ & & \\
\hline & Basic rights & $\begin{array}{l}\text { Do you think you have equal access and opportunity to } \\
\text { public services? }\end{array}$ & & \\
\hline & $\begin{array}{l}\text { and services } \\
\quad 83.5 \%\end{array}$ & $\begin{array}{l}\text { Do you think you are entitled to the same reward for } \\
\text { work of the same value? }\end{array}$ & $2(\max )-1(\min )$ & 2 \\
\hline \multirow{10}{*}{$\begin{array}{l}\text { Vitality } \\
\text { of society }\end{array}$} & $\begin{array}{c}\text { Donation } \\
\text { (time and } \\
\text { money) } \\
43 \%\end{array}$ & $\begin{array}{l}\text { In the past } 12 \text { months, how much money have you } \\
\text { donated to volunteer goals? }\end{array}$ & $\begin{array}{c}100 € \text { and more } \\
(\max )-0-20 € \\
(\min )\end{array}$ & $50-100 €$ \\
\hline & $\begin{array}{l}\text { Relations } \\
\text { in society }\end{array}$ & $\begin{array}{l}\text { To what extent do you trust people in Slovakia } \\
\text { in general? }\end{array}$ & $8(\mathrm{~m}$ & 6 \\
\hline & $28.5 \%$ & To what extent do you trust your neighbours? & (дй & \\
\hline & \multirow{7}{*}{$\begin{array}{l}\text { Family } \\
28.5 \%\end{array}$} & Are your family members interested in each other? & \multirow{7}{*}{$\begin{array}{l}21(\max )-7 \\
(\min )\end{array}$} & \multirow{7}{*}{$21-17$} \\
\hline & & Is your family a real source of comfort for you? & & \\
\hline & & Is there enough understanding in your family? & & \\
\hline & & Do you spend a lot of time with your family? & & \\
\hline & & Do you feel like a stranger in your family? & & \\
\hline & & Do you wish you were not a member of your family? & & \\
\hline & & $\begin{array}{l}\text { Do your family members often quarrel with } \\
\text { each other? }\end{array}$ & & \\
\hline Environment & $\begin{array}{c}\text { Responsibility } \\
\text { towards the } \\
\text { environment } \\
100 \%\end{array}$ & $\begin{array}{l}\text { Do you feel responsible for maintaining a clean } \\
\text { and healthy environment? }\end{array}$ & $4(\max )-1(\min )$ & 4 \\
\hline \multirow[t]{2}{*}{$\begin{array}{l}\text { Living } \\
\text { standards }\end{array}$} & $\begin{array}{c}\text { Household } \\
\text { income per } \\
\text { member } \\
50 \%\end{array}$ & Monthly income. & $\begin{array}{c}901 € \text { and more } \\
(\max )-0-400 € \\
(\min )\end{array}$ & $401-900 €$ \\
\hline & $\begin{array}{l}\text { Housing } \\
50 \%\end{array}$ & Loan. & 1 (yes) -2 (no) & 2 \\
\hline \multirow{2}{*}{ Time use } & $\begin{array}{l}\text { Work } \\
50 \%\end{array}$ & Number of hours worked per day. & $\begin{array}{c}13 \text { and more } \\
(\max )-0-4 \\
(\min )\end{array}$ & $5-8$ hours \\
\hline & $\begin{array}{l}\text { Sleep } \\
50 \%\end{array}$ & Number of hours of sleep per day. & $\begin{array}{c}14 \text { and more } \\
(\max )-0-4 \\
(\min )\end{array}$ & $5-8$ hours \\
\hline
\end{tabular}

Source: own processing. 
When processing respondents' answers to individual variables, it was necessary to divide them into particular domains. The following step consisted in the application of a sufficiency threshold that had to be reached by the respondent in all variables, in order to be considered as happy. Then the weights for each indicator were applied. The weighted average was calculated from these results (Tab. 1). When the weighted average was higher than $66 \%$, the particular domain was evaluated as successful. The overview of their success in the regions of Slovakia is shown in Fig. 2.

The psychological domain was evaluated first. It consisted of indicators such as: life satisfaction, spirituality, positive and negative emotions. With regard to the success rate of the results, this domain reached below-average values (only $35.8 \%$ ) and ranked fifth among other domains. It reached the highest number in the Trnava region (55.8\%), followed by the Banská Bystrica region (46.1\%) and the Bratislava region $(38.5 \%)$. On the other hand, the worst results were registered in the northwestern regions of Slovakia, namely in the Žilina region $(21.0 \%)$ and the Trenčín region $(23.3 \%)$. Low numbers of the researched domain in those regions reflect their low successfulness in two other related domains, the vitality of society and living standards. Psychological well-being indicators can be found in other works, too. Babinčák (2008) was, in his work, dealing with life satisfaction as a psychological dimension. Vendel and Suško (2004) as well as Poloma and Pendleton (1990 in Ira and Andráško 2007) focused on the connection between satisfaction and religion. Emmons and Diener (1985 in Schusterová 2004) suggest monitoring positive and negative emotions as an effective part of subjective well-being.

Health was the second researched domain. Pacione (2003) uses this domain, in some respects, as an equivalent for the quality of life, which also stresses the importance of this domain. The term "health related quality of life" has become established in some literatures (Hancock 2000 in Ira and Andráško 2007). Similarly, Marlin (1992) stresses health as the most important component of the overview of liveability of the US cities. Kačmárová et al. (2013) point out to the quality of life and its relation to health. Massam and Everitt (2001 in Andráško 2016) have found out in their research of Mexican towns, that inhabitants, in terms of the quality of life, attached the biggest importance to family and health. In the use of indicators of health conditions and health restrictions, the success of this domain was within the range of $60.5 \%$ to $73.2 \%$, which gave it the third place, closely followed by the domain of education. The regions with the biggest cities - the Bratislava region $(73.2 \%)$, the Košice region $(73.0 \%)$ and the Prešov region $(70.8 \%)$ - were the most successful. On the contrary, the least successful were the Trnava region $(60.5 \%)$ and the Banská Bystrica region (60.9\%).

Education was the second-most successful domain (67.7\%). Apart from the indicator of the highest attained education, this domain was amended by indicators related to knowledge and values. The successfulness of the domain was within the range of $60.0 \%$ (the Trenčín region) and $78.3 \%$ (the Nitra region). Contrary to the domain of health, this domain reached in the regions with the biggest cities only average values (the Košice region $61.2 \%$, the Prešov region $62.0 \%$, and the Bratislava region $68.8 \%$ ). This fact is quite surprising because Andráško (2005) points out that the factor of education is given greater importance in bigger towns. Murgaš (2009) also stressed the importance of education in his research. He is the first who mentions the indicator of inhabitants with a higher education within the domain of human capital. Ira and Andráško (2007) write that the relationship between the 
quality of life and education has become an objective of attention of many authors (e.g. Glenn and Weaver 1981 and Shinn 1986 in Ira and Andráško 2007). Schusterová (2004) also examined the relationship between education and subjective well-being.

The cultural diversity domain was, in regard to the original methodology of GNH, reduced by the indicators directly related only to Bhutan. Attendence at cultural events was considered as an indicator. In spite of this reduction, the domain was rated as the most successful $(68.7 \%)$. In the Trnava region, it reached $86.4 \%$ and in the Bratislava region $82.3 \%$. It was confirmed that economic evolution supports the development of culture and the interest of inhabitants in their activities (the quoted regions belong, according to the GDP per capita, to the two most developed regions in Slovakia - Fig. 3). This also applies vice versa. As noted in the study on the contribution of culture to local and regional development (Ministerstvo kultúry SR 2010), cultural activity is the essence of a creative economy, whereby the cultural and creative sectors grow faster in comparison to the economy as a whole. Even in other regions the cultural diversity domain was assessed rather higher at the level of $58-74 \%$, except for the Trenčín region (44.6\%).

The good governance domain was ranked fourth $(51.7 \%)$ as for success. Compared to the three most successful domains such as cultural diversity, education and health, it represented a significant difference. With the indicators of the government performance and basic rights and services this domain reached the highest success in the Trenčín region (60.0\%) and in the Bratislava region $(59.2 \%)$, but the lowest $(34.8 \%)$ in the Banská Bystrica region (partly a result of the unsuccessful ope-ration of the far-right party in leading the region after the regional elections in 2013). Various works suggest the eligibility of this domain. Gyourko and Tracy (1991 in Andráško 2016) admitted the connection between the fiscal policy of towns and the quality of life. Andráško (2008) refers to the inhabitants' discontent with the local municipality operations and possibilities of personal influence over the course of events in Bratislava. Mandys (2013) designed a theoretical model of testing the quality of life by municipalities that involves the public into its evaluation.

Vitality of society was another assessed domain. Together with three monitored indicators - donation, relations in society and family, it was ranked sixth $(31.7 \%)$. The highest values were achieved by the Nitra region $(40.8 \%)$ and the Banská Bystrica region $(40.2 \%)$ followed by the Bratislava region $(38.5 \%)$ and the Trnava region $(34.3 \%)$. On the contrary, this domain re-corded expressively lower values in the Zilina region $(20.9 \%)$ and the Trenčín region $(21.0 \%)$. Overall, the level of success of this domain in the regions was rather low. It is in line with Andráško (2005) who states that the respondents as for the personal quality of life mostly preferred human relations and family. Similar findings were also introduced by Bowling (1995 in Ira and Andráško 2007) in a study from Great Britain. The results of this domain can be related to the changes of family life in Slovakia in the form of dynamic fertility postponing, the existence of one-parent families and cohabitations, to which Šprocha et al. (2014) payed attention to in his work. We encounter the third indicator of donation far less often, but it was used by Murgaš (2009) in the form of voluntary contribution enumeration within the event of DaffodilDay.

The environmental domain with the indicator of responsibility towards the natural environment was listed in the last position (29.1\%). Overall, the inhabitants do 
not feel to be as much responsible for their environment, whereby the worst values were recorded in the Trnava region $(20.7 \%)$, the Nitra region $(23.4 \%)$ and the Trenčín region $(25.5 \%)$. On the contrary, this field had the best ranking in the Banská Bystrica region (38.3\%), even though in comparison with the domains such as health and education it was still much lower. Despite the low feeling of responsibility towards the natural environment of the respondents, in several surveys, the inhabitants referred mainly to problems in this area. In the works of Andráško (2004 and 2008) the inhabitants of Považská Bystrica expressed their discontent with the natural environment, and considerable discontent was expressed by the inhabitants of Bratislava as for the cleanness of streets and public places. The low success of this domain does not quite correspond with the findings of Ira and Suška (2006), who, assessing the quality of life in Partizánske, within five domains, identified the environmental area as the most important.

The living standards domain (32.4\%) also belonged to the three least prefered domains. It was assessed by means of indicators of household income per household member and housing loan. It was the least successful in the Žilina region $(23.3 \%)$ and even in the other five regions, the figures of success were not expressively higher (from $26.5 \%$ in the Banská Bystrica region to $30.4 \%$ in the Nitra region). Expressively higher assessment was achieved in the economically strongest regions - Trnava $(43.3 \%)$ and Bratislava $(52.5 \%)$. We consider income and housing as the most important areas of the quality of life. Income, expressed by the average number of employees with the highest and lowest wages, as the indicator was chosen e.g. by Michálek (2008). Blomquist et al. (1998 in Andráško 2016) assessed selected urban areas in the USA considering the level of wages, tenancy and local living conditions. Within the prosperity domain, Murgaš (2009), in addition to the income indicator, also designated motor vehicle possession as the second highest investment following property acquisition. The area of housing and amenities was the second most important (after the environmental) within the assessment by Ira and Šška (2006). Housing also appears to be the key component of housing quality in the work of Ira (2003).

The last, and at the same time least inportant, domain was time use (7.2\%) with its allocation to work and sleep (or more precisely relaxation/free time). Its success was moving in a small interval from $6.2 \%$ (the Bratislava region) to $8.1 \%$ (the Trenčín region). Hectic life, consequences of which were demostrated by the discontent of respondents with the portion between work and leisure, was the main reason. The question is whether, at present, when the line between work and leisure (and private life) fades away, there could occur a perceivable change for the better. The problem with the balance between work and leisure was reflected in the general well-being, whereas even the psychological domain and vitality of society domain were identified as less successful. Even Marans and Kweon (2001 in Andráško 2016) have similarly observed a massive growth of discontent with the amount of free time or time for doing things people "want to do" in the metropolitan area of Detroit in the last four decades. Free time, from the point of view of the quality of life, was assessed by Prokešová (2008) and the relation between leisure and work by Kučerová (1996).

Overall, it is possible to compare the regions on the basis of a course of success in domains: the Bratislava region: 3-1-4-2-2-3-4-1-8 (positions among the regions in the Slovak republic), the Trnava region: 1-8-2-1-7-4-8-2-6, the Trenčín region: 7 -6-8-8-1-7-6-6-1, the Nitra region: 6-4-1-3-3-1-7-3-5, the Žilina region: 8-5-7-6-5- 
8-3-8-3, the Banská Bystrica region: 2-7-3-4-8-2-1-7-2, the Prešov region: 4-3-5-76-5-5-4-7, the Košice region: 5-2-6-5-4-6-2-5-4. In all, the situation in the regions is as follows: the Bratislava region: 4 times $\left(1^{\text {st }}\right.$ or $2^{\text {nd }}$ position): 1 time $\left(7^{\text {th }}\right.$ or $8^{\text {th }}$ position), the Trnava region 4:3, the Banská Bystrica region 4:3, the Nitra region $2: 1$, the Košice region 2:0, the Prešov region 0:2, the Trenčín region 2:4 and the Žilina region 0:4.

Another step following the assessment of domains' success was the identification of two groups of people, namely happy and not-yet-happy. In order for a person to be assessed as happy, they have to reach a certain of happiness threshold in 6 out of 9 domains. The percentage of not-yet-happy people $\left(H_{n}\right)$ is illustrated in Fig. 1 together with the number of unsuccessful domains $\left(A_{n}\right)$, i.e. domains, in which not-yet-happy people did not reach the happiness threshold.

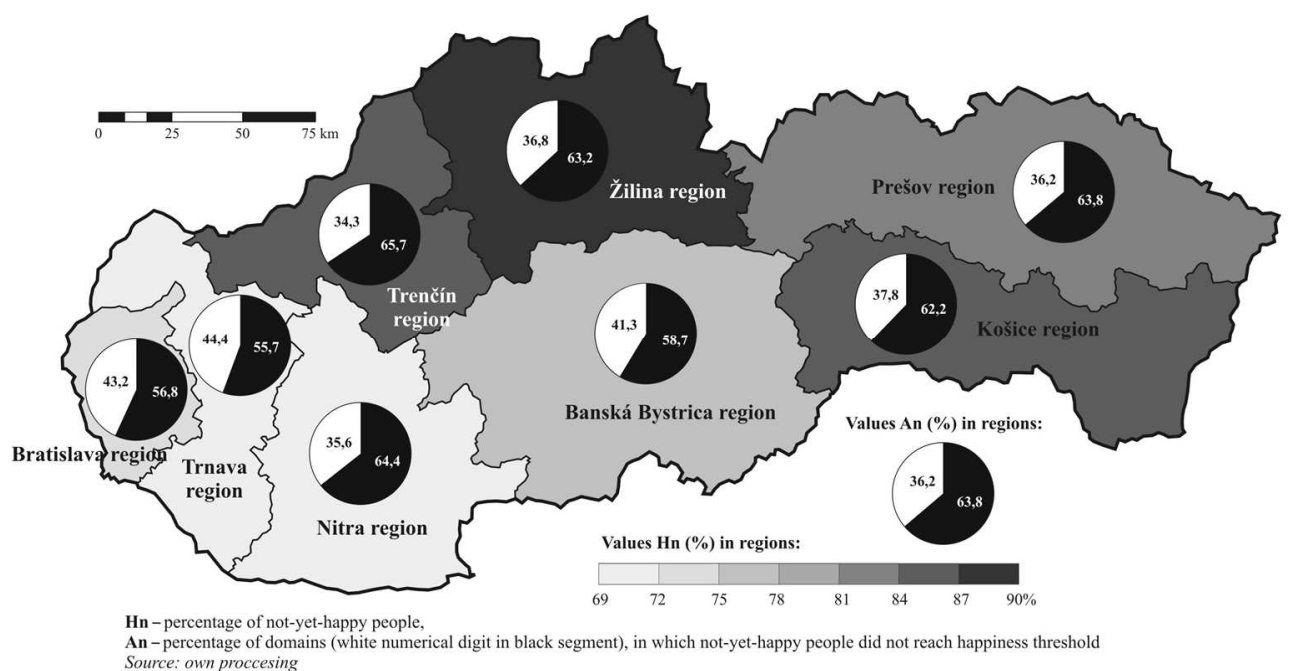

Fig. 1. Values $H_{n}(\%)$ and $A_{n}(\%)$ within the regions in Slovakia

From the results presented in Fig. 1, it is apparent that the most not-yet-happy respondents $\left(H_{n}\right)$ were from the Žilina region $(89.7 \%)$. This region reached four times the last position or last but one in term of domains 'success and did not reach the first two positions at all. Next, the regions at a comparable level followed, namely the Trenčín region $(85.3 \%)$, the Košice region $(84.1 \%)$ and the Prešov region $(83.7 \%)$. The Trenčín region reached the last two positions in four domains, the Prešov region in two domains (the least and the most successful domains). Although, the Košice region achieved the first two positions in two domains, one of them was the environment on the last but one position. More positive values of $H_{n}$ than the average in Slovakia $(78.9 \%)$ were shown in the Banská Bystrica region $(75.2 \%)$ and the Bratislava region $(72.9 \%)$. The least unhappy respondents were in the Trnava region $(69.9 \%)$ and the Nitra region $(69.8 \%)$, and they recorded the best assessment in the biggest number of domains too.

Another parameter was applied in the calculation of the GNH Index, namely $A_{n}$. It denoted the number of domains, in which not-yet-happy people did not reach the 
happiness threshold. The most negative values of An were recorded in the Trenčín region $(65.7 \%)$ and the Nitra region $(64.4 \%)$, although especially in this region, the least percentage of not-yet-happy people was recorded when comparing all the regions. A slightly smaller percentage of not-yet-happy people, who did not reach the happiness threshold was recorded in the Prešov region $(63.8 \%)$, the Žilina region $(63.2 \%)$ and the Košice region (62.2\%). The other three regions with the most positive results in the assessment of the number of not-yet-happy people, also had the highest values of $A_{n}$, and thus the number of domains under the happiness threshold at the lowest level was 55.7\% (the Trnava region), 56.8\% (the Bratislava region) and 58.7\% (the Banská Bystrica region).

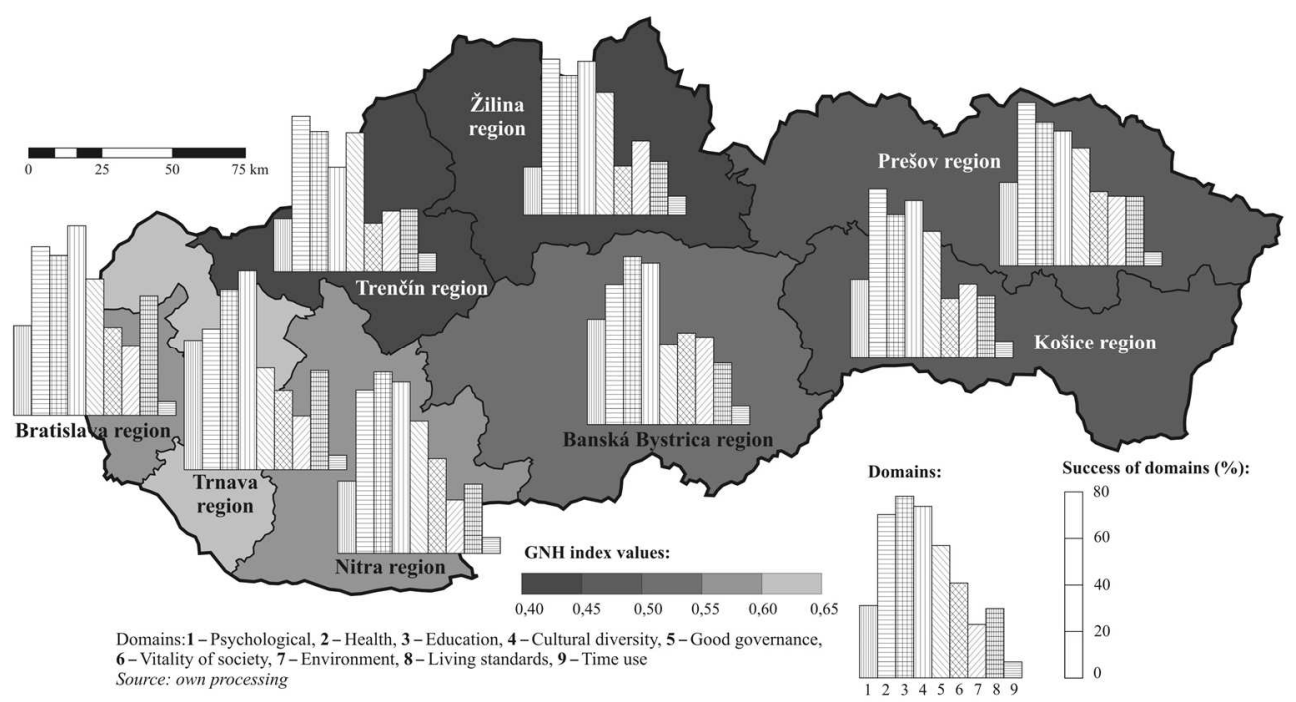

Fig. 2. Success of domains and GNH Index within the regions in Slovakia

The number of not-yet-happy people $\left(H_{n}\right)$ and the number of domains within which the not-yet-happy people did not reach the happiness threshold $\left(A_{n}\right)$ were consequently used in the calculation of the GNH Index. In Slovakia, it remained at around 0.53 and it divided the regions into two main groups or four sub-groups, which were constantly constituted by pairs of neighbouring regions. The first group was constituted by the regions with the GNH Index values lower than the average in Slovakia. The lowest position, with the minimum difference, was occupied by the Žilina region $(0.43)$ and the Trenčín region $(0.44)$. Within both regions there were recorded the lowest values of $H_{n}$ together with $A_{n}$. The slightly higher results were occupied by the Prešov region ( 0.47$)$ and the Košice region $(0.48)$. These regions recorded higher values of $H_{n}$ and $A_{n}$ than the first couple of regions, however, in comparison to the average values in Slovakia $\left(H_{n}-78.9 \%, A_{n}-61.2 \%\right)$ it was more negative. The regions of Nitra (0.55) and Banská Bystrica (0.56) recorded higher values of the GNH Index than the average in Slovakia. In the case of the Banská Bystrica region, the values of $H_{n}$ and $A_{n}$ were higher than the average in Slovakia and in the case of the Nitra region the $H_{n}$ value was highly influential $\left(69.8 \%\right.$ - the best of all the regions), despite the more negative assessment of $A_{n}$ 
(64.4\%). The most positive assessment of the GHN Index was in the Trnava region (0.61) and the Bratislava region (0.59). The Trnava region, generally a highly assessed region, reached the value of $H_{n}(69.9 \%)$ similar to the most positive assessed in the Nitra region, and in terms of the $A_{n}$ value it was also assessed as the most successful $(55.7 \%)$.

The GNH Index belongs to the numerous indexes trying to describe the quality of life, well-being and happiness more complexly. Veenhoven (1996) stated that an analogous multidimensional index, or its construction, is one of the research objectives of social indicators, whereby such an index should be similar to the GDP in economic indicators.

From this point of view, as well as on behalf of the GDP acceptance as the most important economic indicator, we gained a very interesting comparison of the acquired results of the GNH Index and regional GDP per capita in PPS in 2015 (Fig. 3).

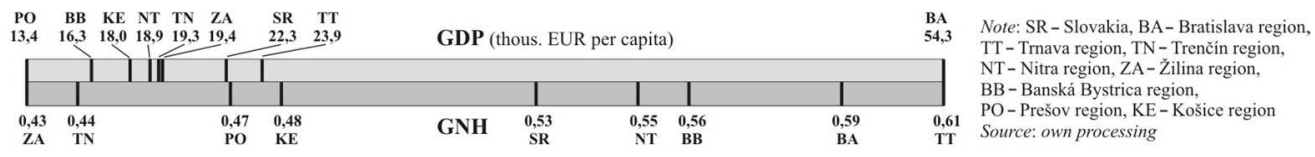

Fig. 3. Comparison of the GNH Index values and regional GDP per capita in PPS (2015) within the regions in Slovakia

Fig. 3 shows the more steady disposition of the GNH Index values in the regions of Slovakia within the range of 0.43 and 0.61 compared to the substantial differences between the Bratislava region (54.3 thousand $€ /$ per capita) and the rest of the regions in Slovakia (from 13.4 to $€ 23.9$ thousand /per capita) in the case of the regional GDP. This conformity assured us that in the economically strongest regions in Slovakia, according to the GDP, namely in the Bratislava region (€54.3 thousand) and the Trnava region ( $€ 23.9$ thousand), the values of the GNH Index were the highest ( 0.59 or more precisely 0.61$)$ and the inhabitants were the most content and the happiest. A higher-than-average, and in the above mentioned regions, the highest values of the GNH Index were recorded in the Nitra region (0.55) and the Banská Bystrica region (0.56) despite the fact that assessing the GDP per capita the listed regions were ranked fifth ( $€ 18.9$ thousand) or even seventh (with only $€ 16.3$ thousand). In the below average of Slovakia (0.53) within the GNH Index, the following regions were assessed: the Prešov region $(0.47)$ and the Košice region (0.48). Both regions had also the lowest values within the GDP, whereas the Prešov region was on a long-term basis ranked as the last one (with only $€ 13.4$ thousand) and the Košice region with value of $€ 18.0$ thousand reached sixth position. Surprisingly, the Žilina and the Trenčín regions occupied the third position ( $€ 19.4$ thousand) and the fourth one ( $€ 19.3$ thousand) when analysing the GDP per capita. As far as the GNH, they ended on the last position (0.43) and on the penultimate position (0.44).

The uneven distribution of values in the case of regional GDP is also evidenced by the fact that, apart from the Bratislava region, the average value of the SR (€22.3 thousand) was exceeded only slightly in the Trnava region (€23.9 thousand). As for the GNH Index it was more balanced - four regions were below the 
Slovak average (0.53) and four were above the average. These significant differences between the values in both evaluations within regions in Slovakia were also confirmed by the coefficient of variation and the Gini coefficient.

In the case of regional GDP, the differences between the regions were more expressive whereby the value of variation coefficient was at the level 0.57 and the Gini coefficient was at 0.22 . Deformations arise from work attendance and the overestimation of strong attendance centres as well as from distortions in regions with a high share of foreign investment, where the GDP includes earnings that are repatriated to the owner's country. The concentration of headquarters of large companies in Bratislava, the capital city, has also a significant impact, although these premises are often situated in other regions of the SR. As the economically strong commuting regions are concentrated in the western part of the country and at the same time, they represent regions with the highest share of foreign investment, there are cumulative distortive effects and increasing disparities between the western and eastern parts of the country and between the capital city and other regions. These and other obstacles in using the GDP have been mentioned, for example, by Lapišáková (2002), Buček et al. (2010), Vintrová (2010), Matlovič and Matlovičová (2011), Nečadová (2012), Murgaš (2015) and others.

The GNH Index points to significantly lower regional differences between rated regions at a level 0.13 (coefficient of variation) and 0.07 (Gini coefficient). It is clear that other key domains such as health, cultural diversity and education (ranging from $57.6 \%$ to $86.4 \%$ ) largely eliminate the strong impact only of the economic aspect as in the case of regional GDP. When comparing the (un)success of individual domains in the Slovak Republic, it is obvious that certain differences are registered due to the regional specifics, but there are not such fundamental levels of differences. This fact has also been confirmed in the case of the least successful domains such as time use, environment, living standards and the vitality of society.

\section{CONCLUSION}

The quality of life, satisfaction with our own life and happiness are the goals of many investigations, what has been also demonstrated in the analysis above. This research paper has evaluated this research area through the regional application of the Gross National Happiness Index using 9 domains. These domains are, in various modifications, a part of other regularly evaluated investigations of the quality of life in EU countries such as the Eurostat or the European Foundation for the Improvement of Living and Working Conditions, which is also demonstrated in the following comparison: GNH Index - psychological, health, education, good governance, vitality of society, environment, living standards, time use, EUROSTAT (2018) - overall life satisfaction, employment/job satisfaction, self-perceived health, education, governance - trust in the legal system, social relations, environment, material living conditions, housing conditions, time use, EUROFOUND (2018) - subjective well-being, health and mental well-being, access and quality of public services, social exclusion and support, participation in society and community, housing, living standard and deprivation, work-life balance and care.

A specific status is given to the Happiness Index published every year by the United Nations in the World Happiness Report, which takes into account a healthy life expectancy, social support, freedom to make life choices, generosity, perceptions of corruption and GDP per capita. According to the latest results (Helliwell et 
al. 2018), Slovakia ranked 39th in the world with the Happiness Index at 6.17 (in the range $1-10$ ), which is close to the average value of the GNH Index (for Slovakia) at 0.53 (in the range $0-1$ ).

The review presented, indicates the need to shift evaluation from purely objective, mainly economic indicators (represented by GDP) presenting prosperity and material prosperity to a more complex approach focusing on life satisfaction, subjective happiness and quality of life as a covering concept. At the same time, it is necessary to look for the corresponding research methodology. As stated by Ira and Andráško (2007), research in this area is characterized by its multidisciplinarity, multidimensionality, but also terminological inconsistency as well as inconsistencies in the methods of measurement.

This research paper is at least a small contribution to this broad research agenda that introduces an effort to explore the issue through the regional application of the GNH Index in the regions in Slovakia. This is one of the first attempts to approach such an application at a regional level, so further discussion will be needed on the issue of the construction of the GNH Index, selection of domains and indicators, determination of the sufficiency and happiness threshold with respect to the conditions in Slovakia, or Central Europe.

This work was supported by the Slovak Research and Development Agency under the contract No. APVV-15-0306, scientific project KEGA 011PU-4/2017 "Integration of teaching and increase of the content coherence of the related disciplines of the specialized module of Regional development and regional policy" and scientific project VEGA 1/0077/17 "Political - spatial structure of the state in conditions of the globalization."

\section{REFERENCES}

ANDRÁŠKO, I. (2004). Percepcia činností samosprávy a vybraných aspektov kvality života (na príklade výskumu medzi obyvatel'mi Považskej Bystrice). In Ira, V., Vaishar, A., eds. Casovo-priestorové aspekty transformačných procesov v Českej republike a v Slovenskej republike. Bratislava (Geografický ústav SAV), pp. 45-51.

ANDRÁŠKO, I. (2005). Dve dimenzie kvality života v kontexte percepcií obyvatel'ov miest a vidieckych obcí. In Vaishar, A., Ira, V., eds. Geografická organizace Česka a Slovenska v současném období. Brno (Ústav geoniky AV ČR), pp. 6-13.

ANDRÁŠKO, I. (2008). Hlavné komponenty spokojnosti s kvalitou životných podmienok v mestských štvrtiach Bratislavy. In Kallabová, E., Smolová, I., Ira,V., eds. Změny regionálních struktur $\check{C} R$ a SR. Brno (Ústav geoniky AV ČR, Univerzita Palackého v Olomouci), pp. 74-79.

ANDRÁSKO, I. (2016). Kvalita života v mestách. Východiská, prístupy, poznatky. Brno (Munipress).

BABINČÁK, P. (2008). Spokojnost’ so životom ako psychologická dimenzia kvality života. Prešov (Prešovská univerzita).

BABINČÁK, P. (2013). Porovnanie troch spôsobov hodnotenia subjektívnej kvality života. In Murgaš, F., ed. Kvalita života 2013. Sborník př́spěvků z mezinárodni konference. Liberec (Technická univerzita v Liberci), pp. 18-27.

BAČOVÁ, V. (2004). Kvalita života, hodnotové systémy v spoločnosti a sociálny kapitál. K vymedzeniu psychologických dimenzií kvality života. In Džuka, J., ed. Psychologické dimenzie kvality života. Prešov (Prešovská univerzita), pp. 9-16.

BIANCHI, G. (2005). Dá sa kvalita života merat? Životné prostredie, 39, 285-289. 
BUČEK, M., REHÁK, Š., TVRDOŇ, J. (2010). Regionálna ekonómia a politika. Bratislava (Iura Edition).

DIENER, E., SUH, E. (1997). Measuring quality of life: Economic, social, and subjective indicators. Social Indicators Research, 40, 189-216.

DISSART, J. C., DELLER, S. C. (2000). Quality of life in the planning literature. Journal of Planning Literature, 15, 135-161.

DŽUKA, J. (2004). Kvalita života a subjektívna pohoda - teórie a modely, podobnost' a rozdiely. In Džuka, J., ed. Psychologické dimenzie kvality života. Prešov (Prešovská univerzita), pp. 42-63.

EUROFOUND (2018). European Quality of Life Survey 2016. European foundation for the improvement of living and working conditions, [Online]. Available: https:// www.eurofound.europa.eu/data/european-quality-of-life-survey [accessed 10 March 2018].

EUROSTAT (2018). Quality of life, [Online]. Available: http://ec.europa.eu/eurostat/cache/ infographs/qol/index en.html [accessed 5 March2018].

GODOR, M., HORNÁK, M. (2010). Možnosti využitia indikátorov vo výskume kvality života v geografii. Geografické informácie, 14, 42-54.

HELliWELL, J., LAYARD, R., SACHS, J. (2012). World Happiness Report 2012, [Online]. Available: $\quad$ http://www.earth.columbia.edu/sitefiles/file/Sachs\% 20Writing/2012/World\%20Happiness \%20Report.pdf [accessed 14 June 2014].

HELliWELL, J., LAYARD, R., SACHS, J. (2018). World Happiness Report 2018. [Online]. Available: http://worldhappiness.report/ed/2018/ [accessed 10 April 2018].

HERMANOVÁ, E. (2012). Kvalita života a její modely v současném sociálním výzkumu. Sociológia, 44, 407-425.

IRA, V. (2003). Územná diferenciácia vybavenosti bytov v SR ako jednej z dimenzií kvality života. In Vaishar, A., Ira, V., eds. České a slovenské regiony na počátku třetího milénia (Sbornik 6. Česko-slovenského akademického semináré z geografie). Brno (Ústav Geoniky AV ČR), pp. 20-26.

IRA, V. (2005). Quality of life and urban space (case studies from city of Bratislava, Slovakia). Europe $X X I, 12,83-96$.

IRA, V. (2010). Krajina, človek a kvalita života. Acta Facultatis Studiorum Humanitatis et Naturae Universitatis Prešoviensis, Folia Geographica, 16, 72-78.

IRA, V., ANDRÁŠKO, I. (2007). Kvalita života z pohl'adu humánnej geografie. Geografický časopis, 59, 159-179.

IRA, V., MICHÁLEK, A., PODOLÁK, P. (2005). Kvalita života a jej regionálna diferenciácia v Slovenskej republike. Životné prostredie, 39, 290-294.

IRA, V., MURGAŠ, F. (2008). Geografický pohl'ad na kvalitu života a zmeny v spoločnosti na Slovensku. Geographia Slovaca, 25, 7-24.

IRA, V., ŠUŠKA, P. (2006). Percepcia kvality života v mestskom prostredí (na príklade mesta Partizánske). Geografická revue, 2, 309-332.

KAČMÁROVÁ, M., BABINĆÁ, P., MIKULÁŠKKOVÁ, G. (2013). Teórie a nástroje merania subjektívne hodnotenej kvality života. Prešov (Prešovská univerzita).

KOLLÁR, V., RUSKO, M. (2012). Kvalita života, terminológia, indikátory a metriky kvality života. In Rusko, M., ed. Globálne sociálne riziká. Zborník z konferencie so zahraničnou účastou, Bratislava, 29. - 30. 2012.Žilina (Strix), pp. 162-182.

KUČEROVÁ, S. (1996). Človek, hodnoty, výchova. Prešov (ManaCon).

LAPIŚÁKOVÁ, J. (2002). Ukazovatele regionálnych účtov a ich úloha pri tvorbe regionálnej politiky. Slovenská štatistika a demografia, 4, 15-21.

MANDYS, J. (2013). Kvalita života jako využitelný indikátor pro potřeby regionální sociální politiky. In Murgaš, F. ed. Kvalita života 2013. Sborník príspěvkì z mezinárodní konference. Liberec (Vysokoškolský podnik Liberec), pp. 86-96.

MARLIN, J. T. (1992). The livable cities almanac. New York (Hasper Collins).

MASSAM, B. H. (2002). Quality of life: public planning and private living. Progress in Planning, 58, 141-227. 
MATLOVIČ, R., MATLOVIČOVÁ, K. (2011). Regionálne disparity a ich riešenie na Slovensku v rozličných kontextoch. Acta Facultatis Studiorum Humanitatis et Naturae Universitatis Prešoviensis, Folia Geographica, 18, 8-87.

MICHÁLEK, A. (2008). Regionálne mzdové nerovnosti v kontexte kvality života na Slovensku. Geographia Slovaca, 25, 25-45.

MINISTERSTVO KULTÚRY SR (2010). Štúdia o prínose kultúry $k$ miestnemu a regionálnemu rozvoju. Konečná správa, [Online]. Available: http://www.culture.gov.sk/ posobnost-ministerstva/kreativny-priemysel/dokumenty-2b7.html [accessed 2 March 2018].

MLČOCH, L. (2005). Ekonomie štěstí: proč méně může být více. Working paper UK FSV - IES, 94, [Online]. Available: http://ies.fsv.cuni.cz/default/file/download/id/2763 [accessed 11 September 2017].

MURGAŠ, F. (2008). Regionálna diferenciácia kvality života na Slovensku. Regionální studia, 2, 13-21.

MURGASS, F. (2009). Kvalita života a jej priestorová diferenciácia v okresoch Slovenska. Geografický časopis, 61, 121-138.

MURGAS̆, F. (2015). Kvalita života jako náhrada obecní míry socio-ekonomického rozvoje v podobě HDP. In Murgaš, F., ed. Kvalita života 2015. Sborník príspěvků z československé konference. Liberec (Vysokoškolský podnik Liberec), pp. 62-75.

NAŠĆÁKOVÁ, J., BEDNÁROVÂ, L., TOMČÍKOVÁ, M. (2015). Ekonomický rast a jeho vplyv na spoločenský blahobyt a kvalitu života. Transfer inovácií, 32, 72-76.

NEČADOVÁ, M. (2012). Je HDP vhodným ukazovatelem ekonomické výkonnosti a sociálního pokroku v podmínkach globalizace? Acta Oeconomica Pragensia, 20, 3-23.

PACIONE, M. (2003). Urban environmental quality and human well-being - a social geographical perspective. Landscape and Urban Planning, 65, 19-30.

PROKEŠOVÁ, M. (2008). Volný čas z hlediska kvality života. Ostrava (Ostravská univerzita).

RIŠOVÁ, K. (2016). Meranie subjektívnej a objektívnej dimenzie kvality života z geografického hl'adiska - prehl'ad prístupov. Acta Facultatis Studiorum Humanitatis et Naturae Universitatis Prešoviensis, Folia Geographica, 58, 54-69.

RYBÁŘOVÁ, M., MAREŠ, J., JEŽEK, S., TƯMOVÁ, Š. (2006). Kvalita života vysokoškoláků zjišt'ovaná metodou SEIQoL. In Mareš, J. et al., eds. Kvalita života u dětí a dospivajícich. Brno (MSD), pp. 189-198.

RUBISOVÁ, M. (2012). Multidimenzionálne indexy - ukazovatele sociálno-ekonomického rozvoja. In Fuchs, K., Šimo, D., Hrdý, M., Wildmannová, M., eds. Nové trendy 2012. Sborník př́spěvků z mezinárodní vědecké konference. Znojmo (Soukromá vysoká škola ekonomická Znojmo), pp. 213-222.

SCHUSTEROVÁ, N. (2004). Hodnoty a subjektívna pohoda. In Džuka, J., ed. Psychologické dimenzie kvality života. Prešov (Prešovská univerzita v Prešove), pp. 95-105.

SPISIIAK, P., DANIHELOVÁ, D. (1998). Niektoré otázky kvality života v suburbánnom priestore Bratislavy. Acta Facultatis Rerum Naturalium Universitatis Comenianae, Geographica, 41, 155-163.

ŠPROCHA, B., VAŇO, B., BLEHA, B. (2014). Prognóza vývoja rodín a domácností na Slovensku do roku 2030. Bratislava (Ekonóm).

URA, K., ALKIRE, S., ZANGMO, T. (2012). An extensive analysis of GNH Index. Centre for Bhutan Studies, [Online]. Available: http://www.grossnationalhappiness.com/wpcontent/uploads/2012/10/An $\% 20$ Extensive $\% 20$ Analysis $\% 20$ of $\% 20 \mathrm{GNH} \% 20$ Index.pdf [accessed 18 February 2014].

VEENHOVEN, R. (1996). Happy life-expectancy: a comprehensive measure of quality-oflife in nations. Social Indicators Reseach, 39, 1-58.

VEENHOVEN, R. (1997). Advances in understanding happiness. Revue Québécoise de Psychologie, 18, 29-74.

VENDEL, Ś., SUŠKO, J. (2004). Viera a spokojnost' žien. In Džuka, J., ed. Psychologické dimenzie kvality života. Prešov (Prešovská univerzita), pp. 502-507. 
VINTROVÁ, R. (2010). Interpretační omezení HDP a alternativní ukazovatele, [Online]. Available: https://is.muni.cz/do/econ/soubory/oddeleni/centrum/papers/17Vintrova.pdf [accessed 25 March 2018].

WHITE, A. G. (2007). A global projection of subjective well-being: a challenge to positive psychology? [Online]. Available: http://data360.org/pdf/20071219073602.A\%20Global $\% 20$ Projection $\% 20$ of $\% 20$ Subjective $\% 20$ Well-being.pdf [accessed 15 July 2014].

Radoslav Kl a már, Anna Gaval'ová

\section{REGIONÁLNA APLIKÁCIA INDEXU HRUBÉHO NÁRODNÉHO ŠŤASTIA V RÁMCI SLOVENSKA V KONTEXTE KVALITY ŽIVOTA}

Príspevok sa venuje regionálnej aplikácii indexu hrubého národného št'astia (Gross National Happiness - GNH) v samosprávnych krajoch SR. Poukazuje na to, že na prosperitu a rozvoj regiónov nie je možné nazerat iba optikou ekonomického rastu (s využitím HDP), ale je potrebné sústredit' sa aj na spokojnost' obyvatel'ov a ich subjektívne št'astie v širšom kontexte kvality života.

Pri koncipovaní metodiky výpočtu indexu sa vychádzalo z pôvodného metodického postupu indexu GNH v Bhutáne komunikujúc potrebnú regionálnu transformáciu s Centrom pre výskum GNH v Thimphu. Index GNH pozostával z 9 domén (psychologická, zdravie, vzdelanie, kultúrna rozmanitost', dobré spravovanie krajiny, vitalita spoločnosti, životné prostredie, životná úroveň a využitie času), ktoré boli bližšie definované súborom 20 indikátorov (z pôvodných 33). Následným krokom bol výber 52 premenných transformovaných do podoby otázok v dotazníku, stanovenie hraničnej hodnoty dostatku a zároveň aplikovanie váh pre jednotlivé indikátory. Potom nasledovalo určenie hraničnej hodnoty št’astia a identifikácia dvoch skupín l'udí, a to št’astní a zatial' nie št'astní l'udia. Ostatným krokom bol výpočet samotného indexu GNH, ktorého hodnoty sa pohybovali v rozmedzí 0 - 1, pričom čím bližšie k 1, tým bola úroveň št’astia vyššia. Pre hodnotenie bolo využitých 817 dotazníkov.

Vypočítané hodnoty indexu GNH sa v priemere pre celé Slovensko pohybovali na úrovni 0,53 a rozdelili kraje do dvoch skupín. Prvú skupinu tvorili kraje s hodnotami indexu GNH nižšími ako priemer SR. Najhoršiu pozíciu mali s minimálnym rozdielom Žilinský kraj $(0,43)$ a Trenčiansky $(0,44)$. O niečo lepšie si počínali Prešovský $(0,47)$ a Košický kraj $(0,48)$. Naopak nadpriemerné hodnoty boli zaznamenané v rámci Nitrianskeho $(0,55)$ a Banskobystrického kraja $(0,56)$ a najlepšie v Bratislavskom $(0,59)$ a Trnavskom kraji $(0,61)$.

Medzi najúspešnejšie domény v jednotlivých krajoch patrili doména zdravia, kultúrnej rozmanitosti a vzdelania na úrovni úspešnosti $(57,6-86,4 \%)$. Naopak, medzi najmenej úspešné patrili využitie času (iba $6,2-8,1 \%$ ), životné prostredie $(20,7-38,3 \%)$, vitalita spoločnosti $(20,9-40,2 \%)$ a životná úroveň $(23,3-52,5 \%)$. Otázka využitia času bola teda vo všetkých krajoch hodnotená najhoršie, pričom dôvodom môže byt' najmä hektická doba, ktorej dôsledky sa prejavili nespokojnost'ou respondentov vo vzt’ahu práca vs. odpočinok.

Pri porovnaní vyrátaného indexu GNH a regionálneho HDP na obyvatel'a sú zrejmé výraznejšie rozdiely medzi krajmi v prípade HDP, a to na úrovni 0,57 (variačný koeficient) a 0,22 (Giniho koeficient) oproti indexu GNH $(0,13$, resp. 0,07). Je zrejmé, že dôležité domény - zdravie, kultúrna rozmanitost' a vzdelanie do značnej miery eliminovali silný vplyv ekonomickej stránky ako v prípade HDP. Pri porovnaní (ne)úspešnosti jednotlivých domén je badatel'né, že sú evidované určité rozdiely vd’aka regionálnym špecifikám, no nie až také zásadné, čo sa potvrdilo aj v prípade najmenej úspešných domén. 
Regionálna aplikácia indexu GNH v krajoch SR sa snaží aspoň o malý prínos do širokej výskumnej agendy smerujúcej ku komplexnejšiemu prístupu orientujúcemu sa na spokojnost' so životom, subjektívne št'astie a kvalitu života ako zastrešujúci koncept. Ide o jeden z prvých pokusov o takúto regionálnu aplikáciu, preto bude potrebná d’alšia diskusia o problematike samotnej konštrukcie indexu GNH a jeho adaptácie vzhl'adom na podmienky Slovenska, resp. strednej Európy. 
